\title{
Digital teaching tools and global learning communities
}

\section{[version 1; peer review: 2 approved]}

\author{
Mary Williams ${ }^{1}$, Patti Lockhart ${ }^{1}$, Cathie Martin²
}

${ }^{1}$ American Society of Plant Biologists, Rockville, MD, 20855, USA

2John Innes Centre, Norwich Research Park, Norwich, NR4 7UH, UK

V1 First published: 05 Mar 2015, 4:59

https://doi.org/10.12688/f1000research.6150.1

Latest published: $20 \mathrm{Jul}$ 2015, 4:59

https://doi.org/10.12688/f1000research.6150.2

\section{Abstract}

In 2009, we started a project to support the teaching and learning of university-level plant sciences, called Teaching Tools in Plant Biology. Articles in this series are published by the plant science journal, The Plant Cell (published by the American Society of Plant Biologists). Five years on, we investigated how the published materials are being used through an analysis of the Google Analytics pageviews distribution and through a user survey. Our results suggest that this project has had a broad, global impact in supporting higher education, and also that the materials are used differently by individuals in terms of their role (instructor, independent learner, student) and geographical location. We also report on our ongoing efforts to develop a global learning community that encourages discussion and resource sharing.

\section{Keywords}

Plant biology, science, education online, education digital, education global, education

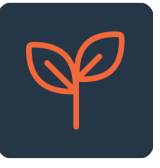

This article is included in the Agriculture, Food and Nutrition gateway.

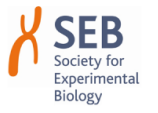

This article is included in the Teaching and communicating science in a digital age collection.

\section{Open Peer Review \\ Approval Status}

1

2

version 2

(revision)

20 Jul 2015

version 1

05 Mar 2015

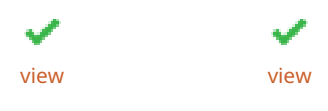

1. Claire Hemingway, National Science Foundation, Arlington, USA

\section{Mirza Hasanuzzaman, Sher-e-Bangla}

Agricultural University, Dhaka, Bangladesh Any reports and responses or comments on the article can be found at the end of the article. 
Corresponding author: Mary Williams (mwilliams@aspb.org)

Competing interests: Mary Williams and Patti Lockhart are employees of the American Society of Plant Biologists (publisher of The Plant Cell), and Cathie Martin is former Editor in Chief of The Plant Cell.

Grant information: The author(s) declared that no grants were involved in supporting this work.

Copyright: @ 2015 Williams $\mathrm{M}$ et al. This is an open access article distributed under the terms of the Creative Commons Attribution License, which permits unrestricted use, distribution, and reproduction in any medium, provided the original work is properly cited. Data associated with the article are available under the terms of the Creative Commons Zero "No rights reserved" data waiver (CC0 1.0 Public domain dedication).

How to cite this article: Williams M, Lockhart $\mathrm{P}$ and Martin C. Digital teaching tools and global learning communities [version 1; peer review: 2 approved] F1000Research 2015, 4:59 https://doi.org/10.12688/f1000research.6150.1

First published: 05 Mar 2015, 4:59 https://doi.org/10.12688/f1000research.6150.1 


\section{Introduction}

More than 20 years ago, the first graphical web browser Netscape Navigator was released, and the world changed forever (Mosaic Communications press release, 1994). Widespread access to the repository of information stored on computers across the globe has changed the way we teach, learn, and communicate. The Internet opened the door to global educational tools, from Wikipedia to massively open online courses (aka MOOCs), and changed the way that students access and engage with information. The opportunities afforded by this international connectedness are still being developed and explored. We describe an innovative, ongoing project to create and disseminate university-level educational materials in plant science by way of their publication in a scholarly journal, we report the new ways these resources are being used across the globe, and we propose new opportunities for enhanced engagement.

\section{Why is plant science important? Food production is a} global challenge

We face many challenges in the $21^{\text {st }}$ century as a consequence of rising population, rising affluence, and energy requirements and global climate changes. It is widely acknowledged that food production must increase by 50\% or more by 2050 (Ray et al., 2013), and at the same time it is vital to preserve natural ecosystems and employ more sustainable food production methods. Food production is a global problem that must be addressed locally, and plant scientists, horticulturalists, and agronomists with local knowledge will be at the forefront of these efforts.

As a first step to addressing the need for increased recruitment and training of plant scientists, the premier plant science journal, The Plant Cell (published by the American Society of Plant Biologists) in 2009 began publishing online educational tools for use in higher education. These materials are presented as a series of articles called "Teaching Tools in Plant Biology". To date we have published 30
Teaching Tools; each includes a set of image-rich PowerPoint slides from which educators can select parts or complete teaching materials, a review-style article written for advanced undergraduates, recommended reading lists that span recent research and review articles as well as historical reports, and teaching guides with questions for discussion and assessment. Each Teaching Tool is peer-reviewed and regularly updated with content and references, features that were impossible before online publishing.

The overarching goal of this project is to support plant scientists in their teaching and learning. The targeted users of these resources are the readers of The Plant Cell (access to the articles requires a personal or institutional subscription to the journal) and their students in upper-level undergraduate or graduate courses. Besides summarizing current plant science, specific objectives are to support a variety of teaching and learning styles, to highlight the relevance of plant research to global issues, and to help bridge the gap between textbook-based learning and learning from the primary literature that occurs as students transition from undergraduate to graduate education.

As online resources, these are used widely across the globe and have been regularly accessed from more than 100 countries. In 2014, the collection received more than 250,000 pageviews. The countries with the greatest number of pageviews were the United States, China, India, Germany, Japan, S. Korea, the United Kingdom, Spain, Canada, and France (Figure 1); each of these countries falls within the top 20 countries in terms of number of Internet users (Internet World Stats, 2014). Although we can track download numbers and sources, we lacked data about who is reading these articles and how they are being used. Therefore, four years into the project, we conducted a survey to learn more about how these resources are used in different countries by instructors, students, and independent learners. A link to the survey was embedded on

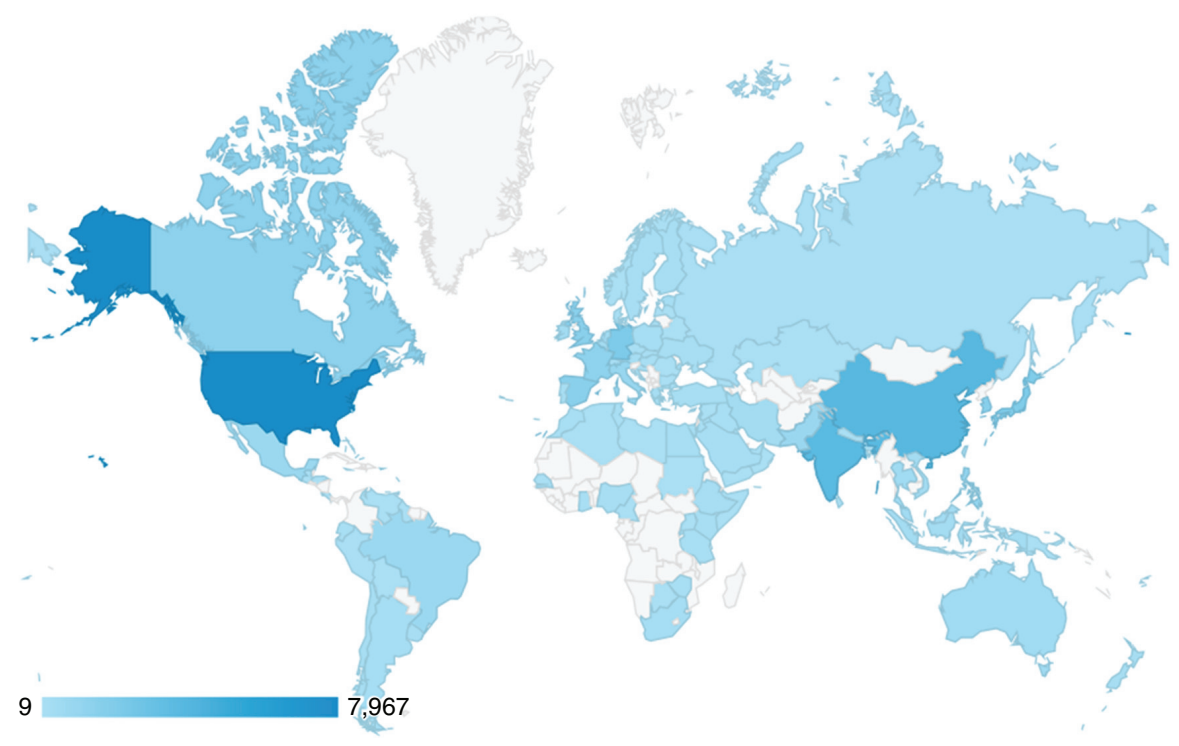

Figure 1. Geographic distribution of Teaching Tools pageviews during 2014, provided by Google Analytics. More than 100 countries are represented in the more than 250,000 pageviews accrued during 2014. Since 2011, the US, China and India have been the countries with the largest number of pageviews. 
the download page for the Teaching Tools resources. To encourage survey completion, we provided a $\$ 100$ Amazon voucher to one randomly selected survey participant. We received nearly 300 completed surveys representing input from 50 countries. About half of our responders were instructors in a course. The remainder were students in a formal course or independent learners not enrolled in a formal course.

\section{Teaching Tools are used in many different ways}

When we initiated this series, we envisioned the articles being used as a supplement to a textbook, and intentionally did not tie them to the content of any of the several textbooks used to teach advanced plant biology or plant physiology. Through our survey, we learned that in some cases both instructors and students have poor access to textbooks (due to financial or language issues) and many are using the materials from The Plant Cell as a substitute for a textbook (Figure 2). A particularly high proportion of survey respondents from least-developed countries who access the materials through Research4Life/AGORA identify as having poor access to textbooks. Now that we recognize that these articles are in some cases being used in lieu of a textbook, we are including more basic as well as advanced coverage of each topic.

Our survey also reinforced the fact that teaching styles and approaches are quite varied. Although in the US there is wide support from learned societies, funding agencies, and many instructors for an emphasis on student-centered, project-based learning, this approach is not universally embraced, particularly outside the US (AAAS, 2011; Freeman et al., 2014; Tanner, 2009). For example, in China higher education styles tend to be more traditional for a variety of social, cultural, and political reasons (Lee, 2004; Thompson \& Ku, 2005; Zhang, 2007; Zhang, 2010). In line with this, $80 \%$ of the survey respondents in China reported that the materials are used in courses that are primarily lecture based, whereas in Asia (without China) and Latin America, the largest category of course types was described as "primarily student centered" (54\% and 55\%) (Figure 3). Respondents from the US or Canada mainly identified their courses "equal parts lecture and non-lecture".

Our survey responses also indicated that the Teaching Tools are being used differently by students, independent learners, and instructors (Figure 4). Course instructors most highly valued the PowerPoint files as sources of images for preparing lectures, students found the Lecture Notes important, and independent learners rated the references as the most important component (independent learner respondents included undergraduates, graduate students, postdocs, lab heads, staff scientists, teaching staff, and other, a category that included librarian, communicator, and entrepreneur).

Although English is the lingua franca of science, about half of the people we surveyed teach or learn in a different language, raising the question of whether we should present these materials in multiple languages. As a first step, we have coordinated the production of translations of one of these lessons, called "Why Study Plants?" into 14 languages (http://www.plantcell.org/site/teachingtools/ TTPB1.xhtml), and we are exploring the possibility of translating additional lessons in collaboration with the Global Plant Council.

\section{Harnessing social media to develop a global learning community}

We have been exploring the use of social media as a way to connect the geographically widespread users of Teaching Tools in Plant Biology. Scientists are generally considered slow adopters of social media, but there is growing awareness that these tools can be used in a professional context and support professional development (Bik \& Goldstein, 2013; Osterrieder, 2013). Since the earliest days of online education, educators have stressed the importance of building community and trust (Brown, 2001; Rovai, 2002); trust is based on positive interactions, whether online or in person. Social media provide the opportunities for community building that were lacking in the earliest iterations of distance learning and have proven to be an effective medium to support interactions among globally

\begin{tabular}{|c|c|c|}
\hline \multicolumn{3}{|c|}{ Out of 155 instructor responses } \\
\hline \multicolumn{2}{|c|}{ Poor access for students } & $\begin{array}{l}\text { Poor access for } \\
\text { instructors }\end{array}$ \\
\hline Argentina $1 / 5$ & Mexico 3/9 & China $1 / 10$ \\
\hline Brazil $1 / 7$ & Paraguay $1 / 1$ & Ethiopia $1 / 1$ \\
\hline Chile $1 / 2$ & Poland 3/4 & Mexico 2/9 \\
\hline China $3 / 10$ & Portugal $1 / 1$ & Turkey $1 / 1$ \\
\hline Colombia 1/1 & Spain $1 / 12$ & Ukraine $1 / 1$ \\
\hline Czech Republic $1 / 2$ & Syria $1 / 1$ & Viet Nam $1 / 1$ \\
\hline Ethiopia $1 / 1$ & Turkey $1 / 1$ & USA 3/28 \\
\hline Germany $1 / 5$ & Ukraine $1 / 1$ & (graduate student, \\
\hline India $1 / 17$ & Viet Nam $1 / 1$ & postdoc, adjunct) \\
\hline
\end{tabular}

Figure 2. Between $6-20 \%$ of respondents in each category reported poor access to textbooks for themselves or their students. This was particularly a concern for respondents from least-developed countries (shown in purple) from which access Teaching Tools in Plant Biology is available through AGORA (Access to Global Online Research in Agriculture).

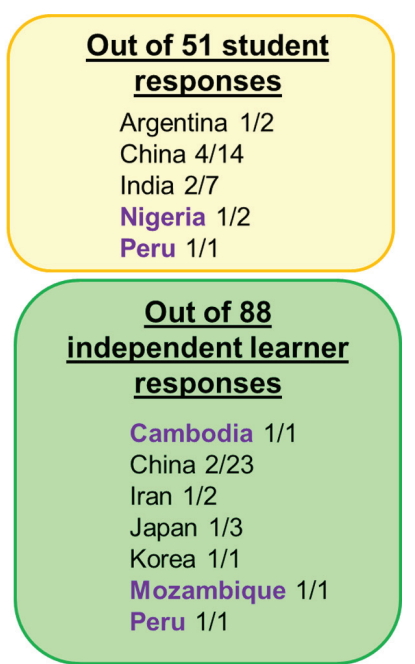

Page 4 of 10 


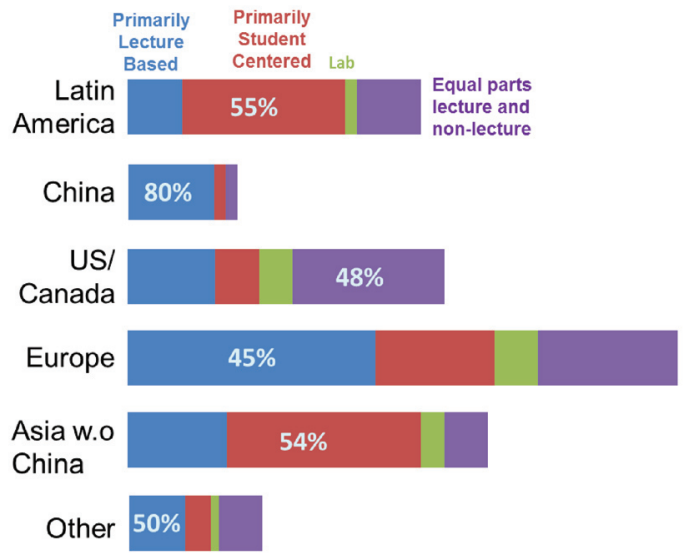

Figure 3. The type of course in which Teaching Tools in Plant Biology materials are used varies for many reasons and depends on institutional, political and cultural practices as well as instructor preferences. This question was only asked to instructors, who selected one category out of the four options indicated. distributed professional communities (Claussen et al., 2013; Davies \& Glasser, 2014; Evans, 2014; Kietzmann et al., 2011). Our efforts so far have focused on three platforms: Twitter, Facebook, and ScoopIt. As described by Van Noorden (2014), Twitter and Facebook are perceived very differently, with far more of the scientists they surveyed indicating that professionally they prefer Twitter to Facebook. Our data indicate that the geographic distribution of people "following" or "liking" the Teaching Tools in Plant Biology feed differs between the two platforms (Figure 5). Notably, more than two thirds of Twitter followers are from the UK, the US, Canada, and Australia, a fact that emphasizes the importance of language for this type of interaction. By contrast, seven out of eight of the largest groups of followers of the Facebook feed are from countries whose primary languages are not English.

The geographically broad distribution of followers of both the Teaching Tools articles and the social media feeds provides an interesting challenge for the content curators and creators, which is to be vigilant about the tone and implications of the materials shared. Many companies and organizations have developed social

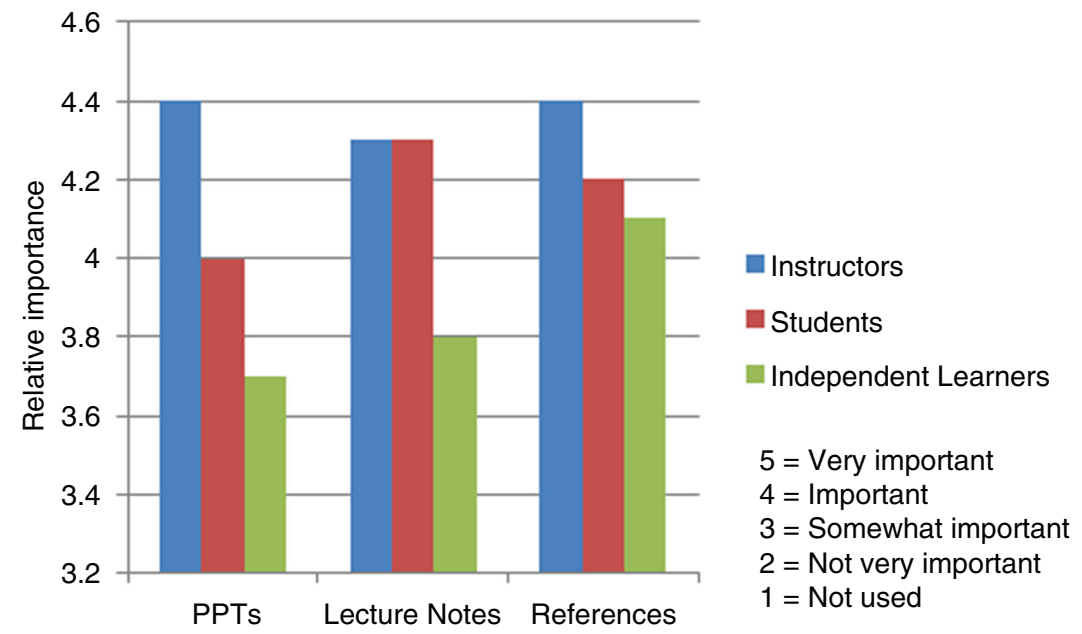

Figure 4. Instructors, students and independent learners have different priorities for the importance of the PowerPoint files, Lecture Notes and References provided in the Teaching Tools. Instructors particularly value the PowerPoint files as sources of images for teaching, the students rank the Lecture Notes as most important, and the independent learners rank the references as most important.
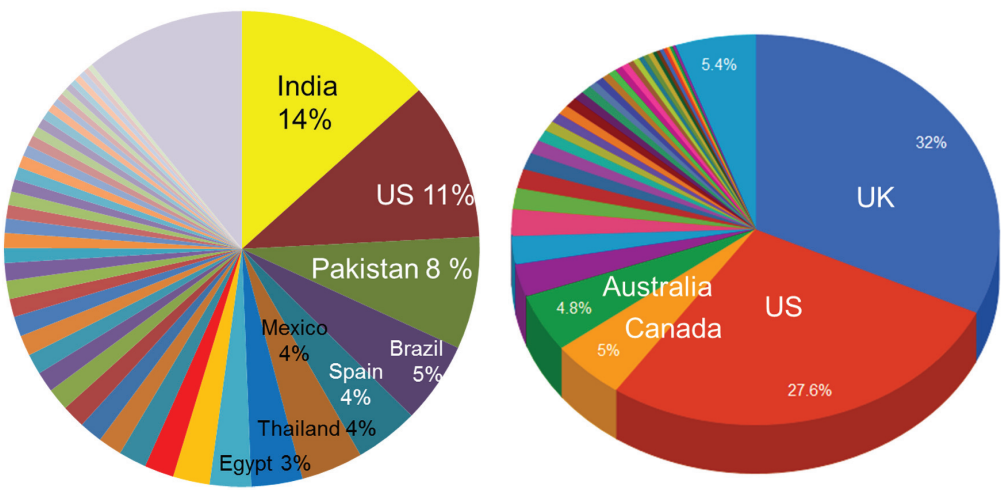

Figure 5. As of December 2014, the geographical origins of followers of Teaching Tools in Plant Biology feeds on Facebook (left, $>\mathbf{3 6 0 0}$ followers) and Twitter (right, $>\mathbf{2 2 0 0}$ followers) are quite different, with Twitter followers showing a strong bias towards countries whose primary language is English. 
media guidelines for their staff to follow (http://socialmediagovernance.com/policies/), and these are particularly relevant when considering diverse audiences. It is possible for a tweet that is meant to be ironic or humorous to be wildly misinterpreted, and there are plenty of well-publicized social media mistakes to serve as reminders of the importance of the rule "think before you tweet". Trust is one of the most important factors for the success of online learning, so providing a positive online presence has been one of our goals (Wang, 2014).

A successful online resource has to reflect the values and concerns of a broadly multicultural community (Liu et al., 2010). To further support the global community of plant scientists, we endeavour to use examples and case studies highlighting agricultural challenges from geographically diverse regions. Recent Teaching Tools describe the challenges of seawater incursion in Bangladesh, groundwater limitations in northern China, and phosphate-deprived soils of Chile and South Western Australia. Contributors to our social media communities are excellent sources of information about regional concerns and perspectives.

Finally, it is clear that our social media platforms are helping to connect the core materials to our audience. As an example, on December $30^{\text {th }}, 2014$, we posted a new Teaching Tool. Forty-eight hours after posting a notice of this new tool on Facebook, the notice had been seen by $>3300$ people, shared 30 times, and been "liked" 56 times, with more than 500 pageviews of the new article.

\section{Moving forward - Supporting interaction and engagement} Through social media, we are creating an environment in which professors, postdocs, and students can share and discuss ideas about current research in plant biology. The platforms we are using now arrange the information chronologically, but later this year we are launching a custom-built platform that will allow the discussions to be archived by theme and topic as well. We are designing the new platform to encourage direct peer-to-peer sharing of teaching tips and strategies. For example, many users of Teaching Tools ask us to suggest videos or animations to accompany the topics, and we will include a simple user interface to support uploading links to such materials. We envision that when an instructor or student is ready to learn "what's new in photosynthesis", he or she can find not only the relevant Teaching Tool, but also links to more recent articles, animations, lesson plans, and teaching ideas contributed from the community. A similar model for introductory biology topics was recently unveiled (CourseSource.org).

\section{Does one size fit all? Should it?}

Our own experiences and several other studies suggest that there are many different ways that teachers and learners can use online educational materials, both in and out of the formal classroom environment. Social and cultural issues, centralized control of curriculum and exams, access to textbooks, and fluency in English all affect the learning experience. Support has been strong for the approach we have taken, which is to make available a diversity of materials suitable for teachers and learners to use as they will. Our strategy has been to create and curate high-quality, authoritative content that highlights and interprets the cutting-edge of plant science, and we are increasingly providing an opportunity for educators and learners to share in the development of these resources. We are confident that through Teaching Tools in Plant Biology we are making a significant contribution to developing the next generation of educational tools with global outreach.

\section{Author contributions}

$\mathrm{CM}$ and MW conceived the project. PL and MW analyzed the pageviews data. MW designed and analyzed the user survey. MW and CM prepared the first draft of the manuscript. All authors were involved in the revision of the draft manuscript and have agreed to the final content.

\section{Competing interests}

Mary Williams and Patti Lockhart are employees of the American Society of Plant Biologists (publisher of The Plant Cell), and Cathie Martin is former Editor in Chief of The Plant Cell.

\section{Grant information}

The author(s) declared that no grants were involved in supporting this work.

\section{Acknowledgements}

We are grateful to Nancy Winchester and Crispin Taylor for comments on the manuscript.
American Association for the Advancement of Science: Vision and Change in Undergraduate Biology Education: A Call to Action. 2011.

Reference Source

Bik HM, Goldstein MC: An introduction to social media for scientists. PLoS Biol. 2013; 11(4): e1001535.

PubMed Abstract | Publisher Full Text | Free Full Text

Brown RE: The process of community-building in distance-learning classes. $J$ Asynchron Learning Networks. 2001; 5: 18-35.

Claussen JE, Cooney PB, Defilippi JM, et al.: Science communication in a digita age: Social media and the American Fisheries Society. Fisheries. 2013; 38(8): 359-362.

Publisher Full Text

Davies BJ, Glasser NF: Analysis of www.AntarcticGlaciers.org as a tool for

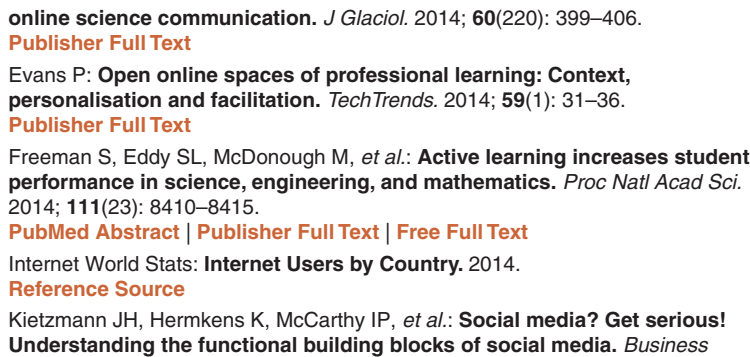


Horizons. 2011; 54(3): 241-251.

Publisher Full Text

Lee D: Web-based instruction in China: Cultural and pedagogical implications and challenges. Educ. Technol. Res. Devel. 2004; 52(1): 101-105.

Publisher Full Text

Liu X, Liu S, Lee SH, et al:: Cultural differences in online learning: International student perceptions. Educ. Technol. Soc. 2010; 13(3): 177-188.

Reference Source

Mosaic Communications Press Release. 1994

Reference Source

Osterrieder A: The value and use of social media as communication tool in the plant sciences. Plant Methods. 2013; 9(1): 26

PubMed Abstract | Publisher Full Text | Free Full Text

Ray DK, Mueller ND, West PC, et al.: Yield trends are insufficient to double

global crop production by 2050. PLOS One. 2013; 8(6): e66428.

PubMed Abstract | Publisher Full Text | Free Full Text

Rovai AP: Building sense of community at a distance. Int Rev Res Open Distrib Learning. 2002; 3(1): 1-16.

Reference Source
Tanner KD: Talking to learn: Why biology students should be talking in classrooms and how to make it happen. CBE Life Sci Edu. 2009; 8(2):

89-94.

PubMed Abstract | Publisher Full Text | Free Full Text

Thompson L, Ku HY: Chinese graduate students' experiences and attitudes toward online learning. Educ Media Int. 2005; 42(1): 33-47.

Publisher Full Text

Van Noorden R: Online collaboration: Scientists and the social network. Nature. 2014; 512(7513): 126-129.

PubMed Abstract | Publisher Full Text

Wang YD: Building student trust in online learning environments. Distance Education. 2014; 35(3): 345-359.

Publisher Full Text

Zhang LJ: A cultural look at information and communication technologies in Eastern education. Educ Technol Res Devel. 2007; 55(3): 301-314.

Publisher Full Text

Zhang J: Technology-supported learning innovation in cultural contexts. Educ. Technol. Res. Devel. 2010; 58(2): 229-243.

Publisher Full Text 


\section{Open Peer Review}

\section{Current Peer Review Status:}

\section{Version 1}

Reviewer Report 08 April 2015

https://doi.org/10.5256/f1000research.6591.r8187

(C) 2015 Hasanuzzaman M. This is an open access peer review report distributed under the terms of the Creative Commons Attribution License, which permits unrestricted use, distribution, and reproduction in any medium, provided the original work is properly cited.

\section{Mirza Hasanuzzaman}

Department of Agronomy, Faculty of Agriculture, Sher-e-Bangla Agricultural University, Dhaka, Bangladesh

This is a nice piece of work which examines how the produced materials are being used by different communities. The authors presented the distribution of the followers of Teaching Tools in Plant Biology on social networks. But in some countries some networks (e.g. Facebook in China) may not be available. How have the authors considered this?

Competing Interests: No competing interests were disclosed.

I confirm that I have read this submission and believe that I have an appropriate level of expertise to confirm that it is of an acceptable scientific standard.

Reviewer Report 07 April 2015

\section{https://doi.org/10.5256/f1000research.6591.r7863}

(C) 2015 Hemingway $\mathbf{C}$. This is an open access peer review report distributed under the terms of the Creative Commons Attribution License, which permits unrestricted use, distribution, and reproduction in any medium, provided the original work is properly cited.

\section{Claire Hemingway}

Division of Graduate Education, National Science Foundation, Arlington, VA, USA

The authors present findings on users of a suite of peer-reviewed digital educational materials available to subscribers of The Plant Cell and describe the efforts to develop this global community. This review of the Teaching Tools in Plant Biology's user community is timely and important for several reasons. 
The importance of this article lies in part on the very fact of the Teaching Tools in Plant Biology's existence. Launching the delivery of university-level digital teaching and learning materials with this high impact journal was a bold venture. Scientific societies that publish journals are faced with altered publishing economies as the landscape shifts from subscription based to open access models. At the same time, most scientific societies are also seeking to meet their education mission in ways that have significant impact and potential to be sustained. The approach to publish education articles with a society's flagship journal remains relatively rare today. Thus, The Plant Cell and the American Society of Plant Biologists deserve recognition for initiating this practice in 2009.

As an opinion piece, the authors present a compelling argument that the Teaching Tools in Plant Biology are needed resources. The website analytics document the global reach of the teaching and learning materials. But the major contribution of this article is the user survey results, which shows the richer picture of who uses the resources, in what ways, and for what reasons. While the authors report that about half of the 300 survey respondents were instructors in a course and half were students enrolled in a course or free-choice learners, more information about the demographics of the respondents would have been useful. The tantalizing finding about the influence of institutional, political, and cultural practices as well as the instructor preferences on material use deserves additional attention as the project moves towards its next phase of harnessing social media to develop a global learning community.

My primary reservation with this opinion piece is the lack of discussion of digital learning resources, and the trend over the years to shift away from digital repositories of resources to communities of practice engaged around the resources. The article frames the introduction in the general context of the radical changes the internet has brought to the ways educational tools are accessed and used. Then in discussing the future directions, the authors briefly mention the openaccess, peer-reviewed journal of evidence-based curricula available at CourseSource. Although I would have liked the authors to present a view of how their materials fit within the constellation of digital learning resources available today, this opinion piece and the Teaching Tools in Plant Biology are a valuable contribution.

Competing Interests: The views expressed here are my own and do not necessarily represent official views of the National Science Foundation.

I confirm that I have read this submission and believe that I have an appropriate level of expertise to confirm that it is of an acceptable scientific standard. 
The benefits of publishing with F1000Research:

- Your article is published within days, with no editorial bias

- You can publish traditional articles, null/negative results, case reports, data notes and more

- The peer review process is transparent and collaborative

- Your article is indexed in PubMed after passing peer review

- Dedicated customer support at every stage

For pre-submission enquiries, contact research@f1000.com 